February 2005 - NREL/CP-520-37404

\title{
Properties of High-Efficiency CIGS Thin-Film Solar Cells
}

\author{
K. Ramanathan, J. Keane, and R. Noufi
}

Prepared for the $31^{\text {st }}$ IEEE Photovoltaics Specialists Conference and Exhibition

Lake Buena Vista, Florida

January 3-7, 2005

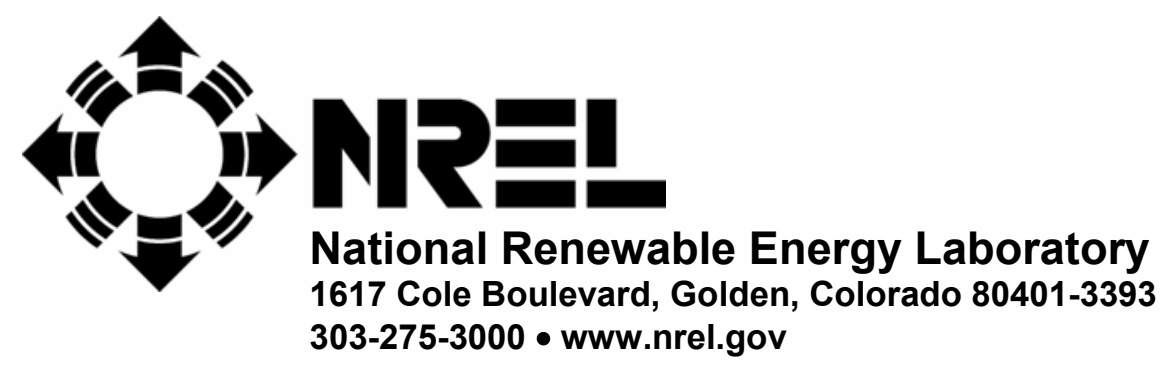

Operated for the U.S. Department of Energy

Office of Energy Efficiency and Renewable Energy

by Midwest Research Institute $\bullet$ Battelle

Contract No. DE-AC36-99-G010337 


\section{NOTICE}

The submitted manuscript has been offered by an employee of the Midwest Research Institute (MRI), a contractor of the US Government under Contract No. DE-AC36-99G010337. Accordingly, the US Government and MRI retain a nonexclusive royalty-free license to publish or reproduce the published form of this contribution, or allow others to do so, for US Government purposes.

This report was prepared as an account of work sponsored by an agency of the United States government. Neither the United States government nor any agency thereof, nor any of their employees, makes any warranty, express or implied, or assumes any legal liability or responsibility for the accuracy, completeness, or usefulness of any information, apparatus, product, or process disclosed, or represents that its use would not infringe privately owned rights. Reference herein to any specific commercial product, process, or service by trade name, trademark, manufacturer, or otherwise does not necessarily constitute or imply its endorsement, recommendation, or favoring by the United States government or any agency thereof. The views and opinions of authors expressed herein do not necessarily state or reflect those of the United States government or any agency thereof.

Available electronically at http://www.osti.gov/bridge

Available for a processing fee to U.S. Department of Energy and its contractors, in paper, from:

U.S. Department of Energy

Office of Scientific and Technical Information

P.O. Box 62

Oak Ridge, TN 37831-0062

phone: 865.576 .8401

fax: 865.576.5728

email: mailto:reports@adonis.osti.gov

Available for sale to the public, in paper, from:

U.S. Department of Commerce

National Technical Information Service

5285 Port Royal Road

Springfield, VA 22161

phone: 800.553 .6847

fax: 703.605.6900

email: orders@ntis.fedworld.gov

online ordering: http://www.ntis.gov/ordering.htm 


\title{
PROPERTIES OF HIGH-EFFICIENCY CIGS THIN-FILM SOLAR CELLS
}

\author{
Kannan Ramanathan, James Keane, and Rommel Noufi \\ National Center for Photovoltaics, National Renewable Energy Laboratory, 1617 Cole Boulevard, Golden CO 80401
}

\begin{abstract}
We present experimental results in three areas. Solar cells with an efficiency of $19 \%$ have been fabricated with an absorber bandgap in the range of 1.1-1.2 eV. Properties of solar cells fabricated with and without an undoped $\mathrm{ZnO}$ layer were compared. The data show that high efficiency cells can be fabricated without using the highresisitivity or undoped $\mathrm{ZnO}$ layer. Properties of CIGS solar cells were fabricated from thin absorbers $(1 \mu \mathrm{m})$ deposited by the three-stage process and simultaneous codeposition of all the elements. In both cases, solar cells with efficiencies of $16 \%-17 \%$ are obtained.
\end{abstract}

\section{INTRODUCTION}

CulnGaSe $_{2}$ (CIGS) polycrystalline thin film photovoltaic cells are a realistic option for reaching the goal of low-cost, high efficiency power conversion from renewable energy sources. Several research groups have reported a steady increase in the efficiency of laboratory devices [13]. Similar progress has been reported in the manufacturing arena, where the efficiency of champion modules has exceeded $13 \%$ and the yield is above $80 \%$ [4]. However, there is a large gap between the efficiency of laboratory cells and commercial modules. This can be narrowed by a concerted effort at the fundamental science of thin film materials and interfaces. Historically, the community has concentrated its efforts on the fabrication and physical properties of the materials themselves and much less on the electronic processes that occur at the interfaces. More attention to this area can lead to a simplification of device structure, and improve the stability and yield of the products. At NREL, we have systematically improved the efficiency of the CIGS solar cells fabricated by the threestage process. Although the deposition method is somewhat difficult to implement in manufacturing, it offers advantages in control of morphology, defects, orientation, bandgap grading, and stoichiometry control. The most efficient CIGS thin film solar cells have been fabricated by the three-stage process. It is now possible to compare the properties of the three-stage devices with those fabricated by other methods and identify areas for improvement.

In this report, we summarize the properties of high efficiency cells fabricated by varying the Ga content of the absorber. Improvement in our understanding of the growth process has resulted in our ability to fabricate solar cells with efficiencies of $18 \%-19 \%$ in the bandgap range of 1.1-1.2 eV. Next, we provide a comparison of the properties of solar cells fabricated using a bilayer $\mathrm{ZnO}$ and a single, conductive $\mathrm{ZnO}$ layer. Finally, we present the properties of solar cells fabricated on thin absorbers.

\section{EXPERIMENTAL}

CIGS absorbers were grown on soda-lime glass substrates with a sputter-deposited Mo layer. The absorber is grown by first depositing an (InGa) ${ }_{2} \mathrm{Se}_{3}$ layer and reacting it with $\mathrm{Cu}$ and $\mathrm{Se}$. Compositional control was achieved by detecting the temperature change of the substrate during Cu-poor to Cu-rich transition at the end of the second stage. The third stage consists of the evaporation of In and $\mathrm{Ga}$ in the presence of Se. Thinner CIGS absorbers were deposited by reducing the $(\mathrm{In}, \mathrm{Ga})_{2} \mathrm{Se}_{3}$ film thickness and making appropriate modifications to the process. Thin absorbers were also prepared by simultaneous deposition of all the elements in one step. CdS deposition was performed using a solution consisting of $0.0015 \mathrm{M} \mathrm{CdSO}_{4}$, $1.5 \mathrm{M} \mathrm{NH}_{4} \mathrm{OH}$, and $0.0075 \mathrm{M}$ thiourea. The samples were immersed in the bath at room temperature and the temperature of the bath was increased to $60^{\circ} \mathrm{C}$. CdS thin films in the thickness range of 50-60 nm were deposited in 16 $\mathrm{min}$. The $\mathrm{ZnO}$ layer was deposited in two stages. A 90nm-thick, undoped layer was first deposited from a pure $\mathrm{ZnO}$ target using $\mathrm{Ar} / \mathrm{O}_{2}$ working gas, and a second layer of about $120 \mathrm{~nm}$ was deposited from an $\mathrm{Al}_{2} \mathrm{O}_{3}$ doped $\mathrm{ZnO}$ target. The sheet resistance of the bilayer was about 65$70 \Omega / s q$. Ni/Al grids were deposited by electron beam evaporation. A $100-\mathrm{nm}$ thick $\mathrm{MgF}_{2}$ film was deposited to serve as an antireflection coating. Current-voltage characteristics of the devices were measured under AM1.5 Global spectrum for $1000 \mathrm{~W} / \mathrm{m}^{2}$ irradiance.

\section{RESULTS AND DISCUSSION}

\section{High Efficiency Solar Cells}

CIGS absorbers with a range of energy gaps were fabricated by adjusting the $\mathrm{Ga}$ content of the $(\mathrm{In}, \mathrm{Ga})_{2} \mathrm{Se}_{3}$ precursor layer. Compositional depth profiles show that the bandgap is graded through the depth of the film. The energy gap was evaluated from spectral response measurements, and the $\mathrm{Ga} /(\mathrm{In}+\mathrm{Ga})$ ratio was derived from the electron microprobe data obtained using $10-\mathrm{kV}$ beam energy. This is indicative of the average composition in a sample volume of approximately $1 \mu \mathrm{m}$. The energy gap ranged from 1.1 to $1.21 \mathrm{eV}$, and the corresponding $\mathrm{Ga} /(\mathrm{In}+\mathrm{Ga})$ ratios ranged from 0.26 to 0.31 . Table 1 shows a summary of the properties of solar cells characterized under standard reporting conditions. Table 2 lists 
the ideality factor and the reverse saturation current density of the solar cells.

Table I. Parameters of high-efficiency CIGS solar cells.

\begin{tabular}{|c|c|c|c|c|}
\hline $\begin{array}{c}\text { Sample } \\
\text { Number }\end{array}$ & $\begin{array}{c}\mathrm{V}_{\mathrm{oc}} \\
(\mathrm{V})\end{array}$ & $\begin{array}{c}\mathrm{J}_{\mathrm{sc}} \\
\left(\mathrm{mA} / \mathrm{cm}^{2}\right)\end{array}$ & $\begin{array}{c}\text { Fill } \\
\text { factor } \\
(\%)\end{array}$ & $\begin{array}{c}\text { Effi- } \\
\text { ciency } \\
(\%)\end{array}$ \\
\hline S2212B1-3 & 0.701 & 34.60 & 79.65 & 19.3 \\
\hline S2212B1-4 & 0.704 & 34.33 & 79.48 & 19.2 \\
\hline S2212B1-5 & 0.703 & 34.08 & 79.23 & 19.0 \\
\hline S2213A1-3 & 0.740 & 31.72 & 78.47 & 18.4 \\
\hline S2213A1-4 & 0.737 & 31.66 & 78.08 & 18.2 \\
\hline S2229A1-3 & 0.720 & 32.86 & 80.27 & 19.0 \\
\hline S2229A1-5 & 0.724 & 32.68 & 80.37 & 19.0 \\
\hline S2229B1-2 & 0.731 & 31.84 & 80.33 & 18.7 \\
\hline S2229B1-4 & 0.728 & 31.87 & 80.16 & 18.7 \\
\hline S2232A1-3 & 0.703 & 33.94 & 79.67 & 19.0 \\
\hline S2232A1-4 & 0.704 & 33.83 & 80.09 & 19.1 \\
\hline S2232B1-2 & 0.717 & 33.58 & 79.41 & 19.1 \\
\hline S2232B1-3 & 0.713 & 33.38 & 79.54 & 18.9 \\
\hline
\end{tabular}

Table II. Diode parameters determined from light currentvoltage curves. $J_{0}$ is the reverse saturation current density, and $\mathrm{n}$ is diode ideality factor.

\begin{tabular}{|c|c|c|}
\hline Device Number & $\mathrm{J}_{0}\left(\mathrm{~A} / \mathrm{cm}^{2}\right)$ & $\mathrm{n}$ \\
\hline $\mathrm{S} 2212-\mathrm{B} 1-3$ & $5 \times 10^{-11}$ & 1.35 \\
\hline $\mathrm{S} 2212-\mathrm{B} 1-4$ & $6 \times 10^{-11}$ & 1.36 \\
\hline $\mathrm{S} 2212-\mathrm{B} 1-5$ & $6 \times 10^{-11}$ & 1.35 \\
\hline $\mathrm{S} 2213-\mathrm{A} 1-3$ & $4 \times 10^{-10}$ & 1.57 \\
\hline S2213-B1-4 & $5 \times 10^{-10}$ & 1.62 \\
\hline
\end{tabular}

The above results suggest that high efficiency CIGS solar cells can be fabricated up to a bandgap of about $1.2 \mathrm{eV}$. The advantage of using a higher band gap is the higher open-circuit voltage and a lower temperature coefficient. This also offers the possibility to reduce the number of cells in a module. High voltages can be maintained along with high fill factors, and the junctions are characterized by low ideality factors and recombination $\left(\mathrm{J}_{0}\right)$.

\section{Simplifying Window Layer Structure}

In the fabrication of CIGS solar cells, it is customary to use a high-low, resistivity grading of the $\mathrm{ZnO}$ layer. An undoped layer of $\mathrm{ZnO}$ (high resisitivity) is first deposited on the CdS, and this is followed by the deposition of a doped layer. Maintaining adequate transparency and achieving resistivity control of films sputtered from two separate targets is not a trivial problem. Moreover, it is not clear whether the undoped layer is an essential part of the device and what role it plays in the junction. If it plays an insignificant role, it can be removed. To evaluate this, we have fabricated solar cells using the bilayer $\mathrm{ZnO}$ and the doped layer only. Absorbers from five growth runs were used for this purpose. Ten samples of each type were prepared on adjacent parts of the absorbers. Each sample contained five solar cells. Hence, the properties of solar cells with bilayer $\mathrm{ZnO}$ could be compared against those with the doped layer fabricated on the same absorber and also against devices fabricated on four other absorber runs. Thus, the distribution of 50 cells of each type becomes a statistically significant population. Figure 1 shows the distribution of $\mathrm{V}_{\mathrm{oc}}, \mathrm{J}_{\mathrm{sc}}$, and Fill factor.
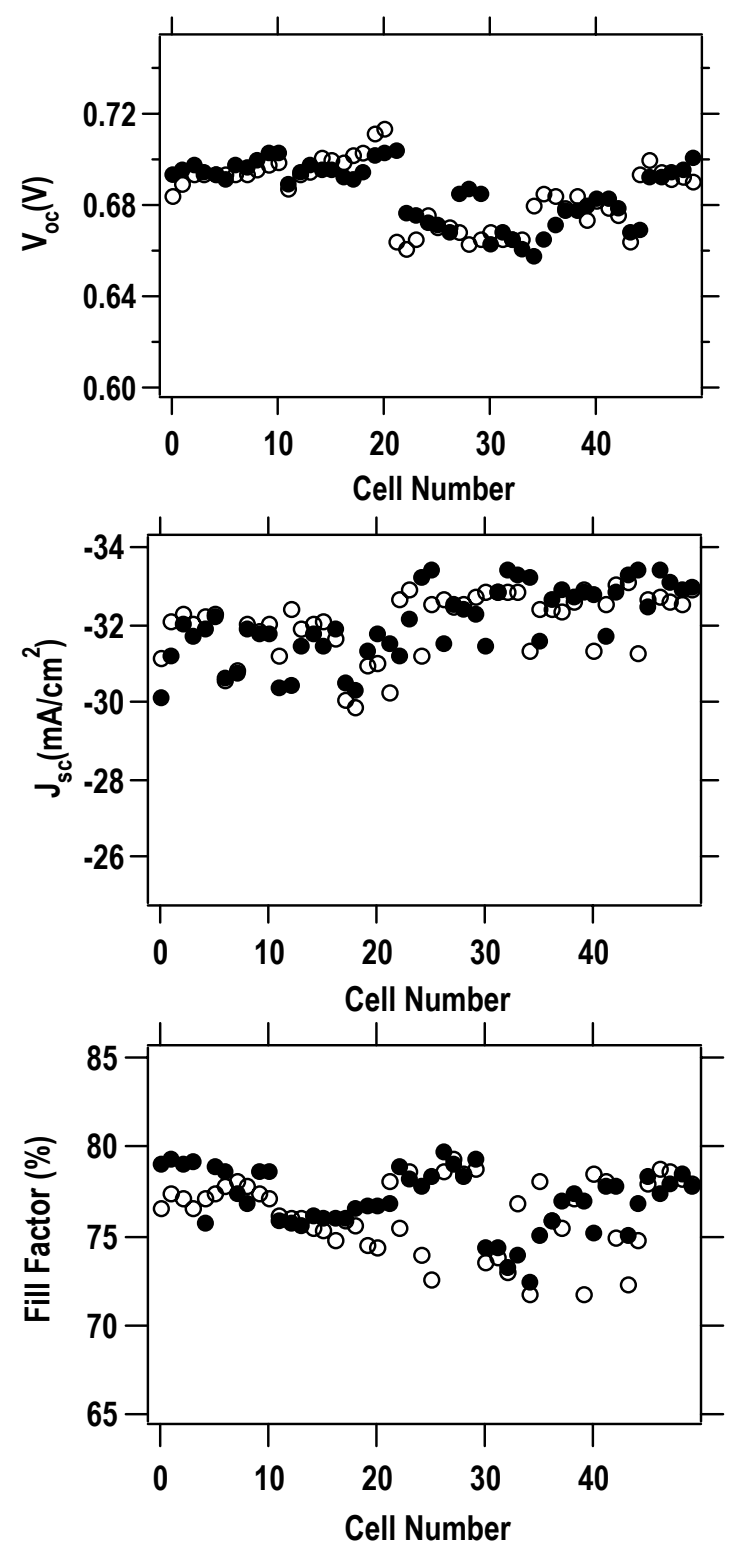

Fig. 1. $\mathrm{V}_{\mathrm{oc}}, \mathrm{J}_{\mathrm{sc}}$ and fill factor of CIGS solar cells. Solid circles: doped $\mathrm{ZnO}$ layer only; open circles: bilayer ZnO.

An inspection of the data in Fig. 1 reveals that the parameters of the solar cells made without the undoped $\mathrm{ZnO}$ layer are identical to those made with the bilayer. It must be pointed out that each sample in this experiment has a spatial variation in the $\mathrm{Ga}$ content along its length, and a similar run-to-run variation exists among the five samples. The experiment was repeated on another sample where the CdS layer was deliberately made much thinner than our standard process and similar results were obtained. The average values of $\mathrm{V}_{\mathrm{oc}}, \mathrm{J}_{\mathrm{sc}}$, FF, and efficiency for the two cases are shown in Table 3. No AR coating was deposited on the above samples. 
Table 3. Properties of CIGS solar cells with doped $\mathrm{ZnO}$ layer and bilayer $\mathrm{ZnO}$. Values for the bilayer are given in parentheses. No AR coating was deposited.

\begin{tabular}{|c|c|c|c|}
\hline $\mathrm{V}_{\mathrm{oc}}(\mathrm{V})$ & $\begin{array}{c}\mathrm{J}_{\mathrm{sc}} \\
\left(\mathrm{mA} / \mathrm{cm}^{2}\right)\end{array}$ & Fill Factor & $\begin{array}{c}\text { Efficiency } \\
(\%)\end{array}$ \\
\hline 0.686 & 32.08 & 0.77 & 17 \\
$(0.685)$ & $(32.06)$ & $(0.76)$ & $(16.8)$ \\
\hline
\end{tabular}

\section{Thin CIGS Solar Cells}

The price and availability of Indium will become dominant concerns for the CIS PV industry when larger-scale production gets under way. One approach to mitigate this would be to reduce the thickness of the absorber layer to a half or quarter of the thickness presently used $(2-2.5 \mu \mathrm{m})$. Indeed, several research groups have explored this issue in some detail $[5,6]$. We have also begun a study of this problem since it has been chosen as a priority research topic for our program. We have made minor modifications to the three-stage process to prepare thinner absorber layers. We have also deposited thin CIGS layers by a single-step co-deposition of all the elements. Absorbers prepared by the three-stage process may be graded band gap materials, whereas co-deposition can provide uniform band gap. A comparison of the materials and devices prepared by the two methods would then allow us to separate out the contributions due to bandgap grading. Fig. 2 shows cross-sectional views of the samples obtained by scanning electron microscopy.

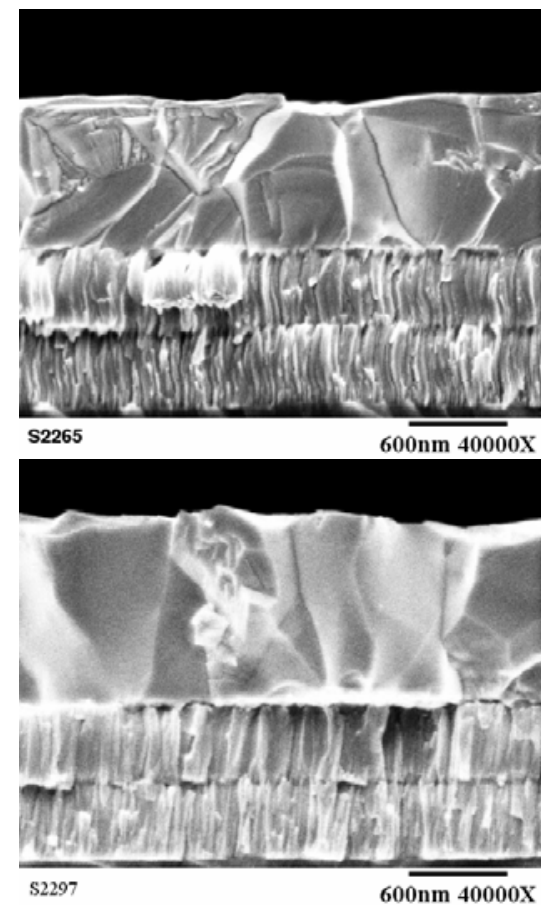

Fig. 2. SEM images of thin CIGS absorbers grown by three-stage (top) and co-deposition (bottom) processes. The bottom layer in each image is a two-layer Mo film.
Solar cells fabricated from the three-stage absorber exhibited open circuit voltages in the range of $650-660 \mathrm{mV}$, current density of $32-33 \mathrm{~mA} . \mathrm{cm}^{-2}$, fill factors of $77-78 \%$, and the best conversion efficiency was $16.5 \%$. When we compare the Jsc of these cells with those of the standard cells in Table 1, we find that the current loss due to thinning the cell is about 2-3 mA.cm ${ }^{-2}$. The external quantum efficiency of a solar cell is shown in Fig. 3. The spectral response curve shows a decrease of the long wavelength collection. This is most likely due to incomplete absorption of the long wavelength photons.

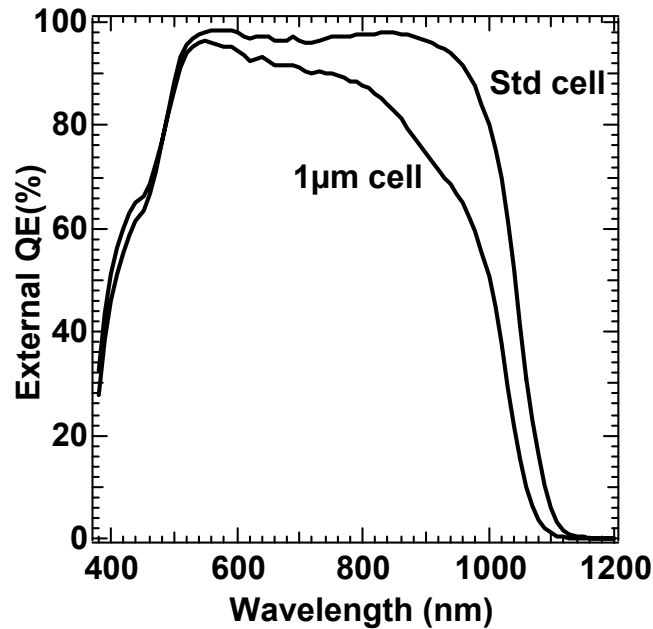

Fig. 3. Quantum efficiency of a thin CIGS solar cell. Also shown is the quantum efficiency of a standard cell.

We have obtained a similar result with absorbers fabricated by co-deposition. The composition of the absorber, determined by electron probe microanalysis was similar to the three-stage absorber. In this case, we obtained an efficiency of nearly $17 \%$. The parameters of the best cells obtained by the two methods are shown in Table 4, below. Further optimization of the growth processes could lead to a higher efficiency. We are also undertaking a study of the recombination processes.

Table 4. Properties of $1-\mu \mathrm{m}$ thick CIGS solar cells fabricated by three-stage process and co-deposition; the latter are shown in parentheses.

\begin{tabular}{|c|c|c|c|}
\hline $\mathrm{V}_{\mathrm{oc}}(\mathrm{V})$ & $\begin{array}{c}\mathrm{J}_{\mathrm{sc}} \\
\left(\mathrm{mA} / \mathrm{cm}^{2}\right)\end{array}$ & Fill Factor & $\begin{array}{c}\text { Efficiency } \\
(\%)\end{array}$ \\
\hline 0.648 & 32.6 & 0.78 & 16.5 \\
$(0.703)$ & $(32.1)$ & $(0.75)$ & $(16.9)$ \\
\hline
\end{tabular}

\section{CONCLUSIONS}

We have reported the properties of CIGS cells with bandgaps in the range of 1.1-1.2 eV and demonstrated the ability to achieve high efficiency. High open-circuit voltages are obtained in conjunction with high fill factors. A study of the properties of the solar cells with and without the undoped $\mathrm{ZnO}$ layer strongly suggests that highly efficient cells can be fabricated without using the undoped $\mathrm{ZnO}$ layer even when the CdS layer is made very thin. 
This might allow simplification of the device processing. We have also reported high efficiency cells (16\%-17\%) using CIGS absorbers in the thickness range around 1 $\mu \mathrm{m}$.

\section{ACKNOWLEDGMENTS}

This work was performed for the U.S. DOE PV Program under Contract No. DE-AC36-99G010337 to NREL. The authors would like to thank M.A. Contreras, F.S. Hasoon, and R. Bhattacharya for helpful discussions; B. To, J.S. Ward, J. Dolan and J. Alleman for technical assistance; T. Moriarty for cell characterization; and L.L. Kazmerski for his encouragement.

\section{REFERENCES}

[1] T. Negami, Y. Hashimoto, and S. Nishiwaki, " $\mathrm{Cu}(\mathrm{In}, \mathrm{Ga}) \mathrm{Se}_{2}$ thin-film solar cells with an efficiency of 18\%," Solar Energy Materials and Solar Cells, 67, 2001, pp. 331-335.
[2] K. Ramanathan, M.A. Contreras, C.L. Perkins, S Asher, F.S. Hasoon, J. Keane, D. Young, M. Romero, W. Metzger, R. Noufi, J. Ward, and A. Duda, "Properties of $19.2 \%$ efficiency $\mathrm{ZnO} / \mathrm{CdS} / \mathrm{CuInGaSe}_{2}$ thin film solar cells," Prog. Photovolt: Res. Appl. 11, 2003, pp. 225-230. [3] J. Kessler, M.Bodegard, J. Hedstrom, and L. Stolt, "Baseline $\mathrm{Cu}(\mathrm{In}, \mathrm{Ga}) \mathrm{Se}_{2}$ device production: control and statistical significance," Solar Energy Materials and Solar Cells, 67, 2001, pp. 67-76.

[4] D.E. Tarrant, R. Gay, V. Probst, and F. Karg, "CIS thin film development and product status at Shell Solar, May 2003," $3^{\text {rd }}$ WCPEC, Osaka, Japan, May 2003.

[5] T.Negami, S. Nishiwaki, Y. Hashimoto, and N. Kohara, "Effect of the absorber thickness on performance of $\mathrm{Cu}(\mathrm{In}, \mathrm{Ga}) \mathrm{Se}_{2}$ solar cells," Proceedings of the $2 \mathrm{nd}$ WCPEC, Vienna, 1998; pp. 1181-1184.

[6] O. Lundberg, M. Bodegard, J. Malmstrom, and L. Stolt, Influence of the $\mathrm{Cu}(\mathrm{In}, \mathrm{Ga}) \mathrm{Se}_{2}$ thickness and $\mathrm{Ga}$ grading on solar cell performance," Prog. Photovolt: Res. Appl: 11, 2003, pp. 77-88. 


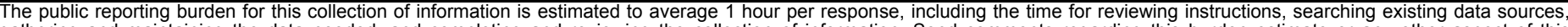

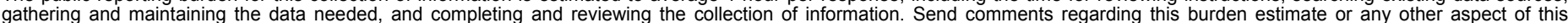

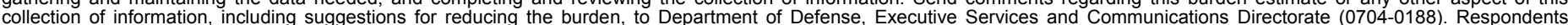

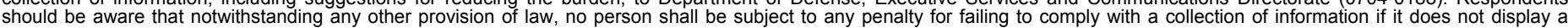

should be aware that notwithstanding

PLEASE DO NOT RETURN YOUR FORM TO THE ABOVE ORGANIZATION.

\section{REPORT DATE (DD-MM-YYYY) \\ February 2005}

4. TITLE AND SUBTITLE

Properties of High-Efficiency CIGS Thin-Film Solar Cells
3. DATES COVERED (From - To)

3-7 January 2005

5a. CONTRACT NUMBER

DE-AC36-99-GO10337

5b. GRANT NUMBER

5c. PROGRAM ELEMENT NUMBER

5d. PROJECT NUMBER

NREL/CP-520-37404

5e. TASK NUMBER

PVA54301

5f. WORK UNIT NUMBER
7. PERFORMING ORGANIZATION NAME(S) AND ADDRESS(ES)

National Renewable Energy Laboratory

1617 Cole Blvd.

Golden, CO 80401-3393
8. PERFORMING ORGANIZATION REPORT NUMBER

NREL/CP-520-37404

9. SPONSORING/MONITORING AGENCY NAME(S) AND ADDRESS(ES)

10. SPONSOR/MONITOR'S ACRONYM(S) NREL

11. SPONSORING/MONITORING AGENCY REPORT NUMBER

12. DISTRIBUTION AVAILABILITY STATEMENT

National Technical Information Service

U.S. Department of Commerce

5285 Port Royal Road

Springfield, VA 22161

13. SUPPLEMENTARY NOTES

\section{ABSTRACT (Maximum 200 Words)}

We present experimental results in three areas. Solar cells with an efficiency of $19 \%$ have been fabricated with an absorber bandgap in the range of 1.1-1.2 eV. Properties of solar cells fabricated with and without an undoped ZnO layer were compared. The data show that high efficiency cells can be fabricated without using the high-resisitivity or undoped $\mathrm{ZnO}$ layer. Properties of CIGS solar cells were fabricated from thin absorbers ( $1 \mu \mathrm{m})$ deposited by the three-stage process and simultaneous co-deposition of all the elements. In both cases, solar cells with efficiencies of $16 \%-17 \%$ are obtained.

\section{SUBJECT TERMS}

PV; high efficiency; solar cells; window layer structure; absorber bandgap; three-stage process;

16. SECURITY CLASSIFICATION OF:
\begin{tabular}{|l|l|l|}
\hline a. REPORT & b. ABSTRACT & c. THIS PAGE \\
Unclassified & Unclassified & Unclassified \\
& & \\
\hline
\end{tabular}

\begin{tabular}{|c|c|} 
17. LIMITATION \\
OF ABSTRACT \\
UL
\end{tabular}

19a. NAME OF RESPONSIBLE PERSON

19b. TELEPHONE NUMBER (Include area code) 